Distribución y estado actual del conocimiento del perezoso de dos dedos de Hoffmann (Choloepus hoffmanni) en Colombia, con comentarios sobre sus variaciones morfológicas externas

\title{
Distribution and current state of knowledge of Hoffmann's two-toed sloth (Choloepus hoffmanni) in Colombia, with comments on the variations of its external morphological traits
}

\author{
Tinka Plese ${ }^{1 *}$, Nicolás Reyes-Amaya ${ }^{2}$, Leyn Castro-Vásquez ${ }^{3}$, Sebastian Giraldo ${ }^{1}$, Orlando Feliciano ${ }^{4}$. \\ ${ }^{1}$ Fundación AIUNAU. Circular Primera, No. 73-20, Medellín, Colombia. E-mail:f.aiunau@gmail.com (TP), sgg148@gmail.com (SG). \\ ${ }^{2}$ Unidad Ejecutora Lillo (CONICET-FML). Miguel Lillo 251, San Miguel de Tucumán, Argentina. E-mail: nicolas.reyes2@gmail.com \\ (NRA). \\ ${ }^{3}$ Universidad del Atlántico, Facultad de Ciencias Básicas, Programa de Biología. Barranquilla, Colombia. E-mail: leyncastro@gmail. \\ com (LCV). \\ ${ }^{4}$ Fundación Bioandina Colombia (FBC). Guasca, Colombia. E-mail: orfelvet@hotmail.com (OF). \\ ${ }^{*}$ Corresponding author
}

Hoffmann's two-toed sloth (Choloepus hoffmanni) has been extensively studied since the 1940s in some countries across its distribution range. However, several aspects of its biology remain unexplored or have been described superficially. This study updated the geographic distribution of this sloth species in Colombia, describing external traits of specimens that inhabit different areas of the country. Additionally, a revision of the current state of knowledge of this species in Colombia was conducted, with a focus on the identification of information gaps and the major threats affecting this species. An updated map of the distribution of $C$. hoffmanni in Colombia was elaborated, including the distribution reported by IUCN, the records of specimens received in the Xenarthra center for rescue and rehabilitation (CRRX, for its acronym in Spanish; primary information), the wildlife care centers of the Autonomous Regional Corporations (CARs, for its acronym in Spanish), and records of biological collections available online (secondary information). CRRX specimens were examined externally, and the external morphological characteristics (skull and body shape; pelage color, length and density) were described. A comprehensive literature review was performed, compiling studies conducted over the last two decades on this species in Colombia, analyzing their respective contributions to its knowledge. The records obtained provide localities of occurrence for the species not previously recognized by IUCN, in 54 municipalities of 12 departments of Colombia. There are external morphological patterns defining lowland (interandean valleys and Caribbean region), highland (Colombian Andes) and Colombian Pacific populations. The biggest information gaps regard demography, distribution and genetics. The main threats identified are habitat loss (infrastructure construction, forest clearance) and removal of specimen (illegal trade). The localities of occurrence obtained confirm the distribution of this species in areas previously suggested at the north and center of the Cordillera Occidental, Cordillera Central and Cauca River valley, besides the north, center and south of the Cordillera Oriental, Piedemonte Llanero, and the southern Magdalena River valley. The external revision of specimens from the CRRX shows that although it is impossible to derive clear taxonomic inferences from the evidence collected, pelage color, length and density are the most representative external traits that differentiate lowland, highland and Pacific Colombian populations. The prioritization of issues such as the conservation status and threats in the investigation of this species in Colombia during the last twenty years have relegated key aspects such as demography, distribution, taxonomy and genetics, a fact that poses a challenge for the execution of proper management actions in the country.

Key words: Choloepus hoffmanni; conservation; distribution; population density.

El perezoso de dos dedos de Hoffmann (Choloepus hoffmanni) ha sido ampliamente estudiado desde la década de 1940 en algunos países de su distribución. Sin embargo, aún son varios los aspectos de su biología que permanecen inexplorados o vagamente descritos. En el presente estudio se realiza una actualización de la distribución geográfica de este perezoso en Colombia, describiendo caracteres externos de ejemplares para diferentes zonas del país. Adicionalmente se realiza un recuento del estado actual de su conocimiento en Colombia, con un enfoque dirigido hacia la identificación de vacíos de información y sus principales amenazas. Se realizó un mapa actualizado de la distribución de C. hoffmanni en Colombia, incluyendo la realizada por la UICN, los registros de ejemplares recibidos por el Centro de Rescate y Rehabilitación de Xenarthras (CRRX, información primaria), los centros de atención y valoración 
de fauna de las Corporaciones Autónomas Regionales (CARs), y los registros de colecciones biológicas disponibles en línea (información secundaria). Se examinaron externamente los ejemplares del CRRX, describiendo caracteres morfológicos externos (forma del cráneo y torso, color, largo y densidad del pelaje). Se realizó una revisión bibliográfica exhaustiva, compilando estudios realizados durante las últimas dos décadas sobre esta especie en Colombia, analizando sus aportes al conocimiento de la misma. Los registros obtenidos aportan localidades de ocurrencia de la especie anteriormente no consideradas por la UICN, en 54 municipios de 12 departamentos de Colombia. Existen patrones morfológicos externos definiendo poblaciones de tierras bajas (valles interandinos y el Caribe), altas (Andes colombianos) y del Pacífico colombiano. Los principales vacíos de información están asociados a aspectos de su demografía, distribución y genética. Las principales amenazas identificadas son la pérdida de hábitat (construcción de infraestructura, tala del bosque) y la extracción de individuos (tráfico ilegal de ejemplares). Las localidades de ocurrencia obtenidas confirman la distribución de esta especie en zonas previamente sugeridas sobre el norte y centro de la Cordillera Occidental, Cordillera Central y valle interandino del río Cauca, además del norte, centro y sur de la Cordillera Oriental, el piedemonte llanero, y sur del valle interandino del río Magdalena. La revisión externa de los ejemplares obtenidos por el CRRX muestra que si bien no es posible establecer inferencias taxonómicas claras con la evidencia recopilada, el color, longitud y densidad del pelaje son los caracteres externos más representativos que están diferenciando poblaciones de tierras bajas, altas y del Pacífico colombiano. La priorización de aspectos como el estado de conservación y amenazas en la investigación de esta especie en Colombia durante los últimos veinte años ha ocasionado que aspectos cruciales como su demografía, distribución, taxonomía y genética hayan sido relegados, hecho que representa un desafío para la formulación de medidas correctas de manejo en el país.

(c) 2016 Asociación Mexicana de Mastozoología, www.mastozoologiamexicana.org

\section{Introduction}

Two-toed sloths (Choloepus spp.) are neotropical mammals belonging to the Order Pilosa (superorder Xenarthra) and the Family Megalonychidae, with two species recognized to date: $C$. hoffmanni and C. didactylus (Gardner 2008; Hayssen 2011). Both species are associated to the canopy of continuous forest coverages dominated by mature and lush trees in rain forest, dry forests and riparian forest ecosystems (Montgomery and Sunquist 1975; Eisenberg 1989).

The species Choloepus hoffmanni has two distribution areas in the Neotropics. The first spans from southern Honduras to northern South America, comprising Colombia, western Venezuela and northern Ecuador; the second is distributed in the Peruvian, Brazilian and Bolivian Amazon (Wetzel 1982; Superina et al. 2010; Hayssen 2011). In Colombia, sloth have been reported in the natural regions of the Caribbean, the Andes and the Pacific, at different altitudes that range from sea level to 3,200 m (Alberico et al. 2000; Moreno 2003; Acevedo-Quintero et al. 2011; Hayssen 2011; Solari et al. 2013).

Five C. hoffmanni subspecies are recognized: $C$. h. juruanus, C. h. pallescens, C. h. agustinus, $C$. h. capitalis and C. h. hoffmanni (Gardner 2008). Three of them have been reported in Colombia: $C$. $h$. agustinus, in the central area and the eastern border with Venezuela; $C$. $h$. capitalis, in the southern Pacific and the southern border with Ecuador; and C. h. hoffmanni, in the Caribbean zone to the northeast of the country and along the Andes western cordillera to the south (Hayssen 2011). C. hoffmanni has not been assigned a threat category by the Ministry of the Environment and Sustainable Development of Colombia (MADS 2014a), and is listed as Least Concern (LC) by the International Union for the Conservation of Nature (IUCN) due to its wide distribution and its alleged tolerance to habitat alterations (Superina et al. 2010).

Although this sloth is considered to be a widely distributed species in Colombia (Alberico et al. 2000; Solari et al. 2013), there are still locations within its distribution range, phenotypical variations and conservation threats that remain unknown or have been scarcely explored. The present work is highly relevant since it carries out a comprehensive review of the current state of knowledge of this species, identifying information gaps, updating its geographical distribution range in Colombia, and describing external morphological traits that are unique to specimens from different areas of the country. This information provides new insights for the proper analysis of the current status as threatened species in the country, as well as for the decision-making related to the conservation of this species. 


\section{Methods}

Records were reviewed of seizures and voluntary deposite of $C$. hoffmanni specimens received by the Xenarthra center for rescue and rehabilitation at AIUNAU foundation (CRRX, primary information), during the past thirteen years (2002-2015; $n=245$ specimens). Also reviewed were data on specimens received by the wildlife care center and evaluation centers at the Autonomous Regional Corporations (CARs, secondary information) corresponding to Antioquia, Cundinamarca, Caldas, Huila, Quindío and Risaralda, over the last five years (2010-2015; $n=334$ specimens; Table 1). For each record, we considered the known locality where the specimen was extracted (municipality and department), investigation that recorded the source of the specimens in the seizure or the information provided by captors during the voluntary deposit. Specimens received in these wildlife care center for which no information was available on their natural origin were excluded from the present work. A review was conducted of the collection records in Colombia for this species in the biological collection databases available in the Global Biodiversity Information Facility (GBIF), Mammal Networked Information System (MaNIS), System of Information on Biodiversity of Colombia (SIB; sources that include data from the biological collections of the American Museum of Natural History, AMNH; Field Museum of Natural History, FMNH; United States National Museum, USNM; Instituto Alexander von Humboldt, IAvH; Mammals Museum at Pontificia Universidad Javeriana, MPUJ-MAMM), and the online records of the Alberto Cadena Garcia Mammal Collection of the Instituto de Ciencias Naturales of Colombia (ICN; Appendix 1). From these revisions, the records of localities of occurrence not included in the distribution previously established by IUCN in 2010 (Superina et al. 2010; Figure 1), were depicted onto a map of Colombia. The geographic distribution reported by IUCN was developed through the analysis of records of biological collections available at the time, and currently used by the Ministry of the Environment and Sustainable Development of Colombia (MADS, for its acronym in Spanish) as the basis for the implementation of management and conservation actions for C. hoffmanni.

All the specimens received by CRRX ( $n=245$ specimens) were examined externally at the time of admission, and the identifiable external diagnostic traits were described (skull shape; body shape; pelage color, density and length; Table 2). The specimens examined included 181 individuals inhabiting the lowlands $(<1,500 \mathrm{~m})$ "comming from the departments the departments of Córdoba, Sucre, Atlantico, Bolivar, Magdalena (Colombian Caribbean), Antioquia, Caldas and Huila (interandean valleys); 59 individuals inhabiting the highlands ( $\geq 1,500 \mathrm{~m})$, from the departments of Antioquia, Cundinamarca, Caldas, Risaralda, Quindío and Boyacá (Colombian Andes); and five individuals inhabiting the Colombian Pacific, from the departments of Chocó (municipality of El Carmen del Atrato, 4 specimens; 1,700 m) and Nariño (municipality of Tumaco, 1 specimen; 50 $\mathrm{m}$ ). Each of these specimens (most of them having been just removed from their habitat) was photographed at the time of reception in CRRX to document its external morphology, avoiding physical handling to the maximum extent possible in order to prevent deaths resulting from potential myopathies secondary to stress by handling (Kreeger et al. 2002). The adults received in CRRX were reincorporated to their natural habitat in the shortest possible time according to their extent of recovery, while neonates and juveniles (unable to survive without their mothers) were attended in this center until their rehabilitation allowed the release.

Studies conducted for this species in Colombia in the last two decades were gathered, and the contribution of each one to the knowledge of this species was analyzed. The studies reviewed were classified according to the biological aspect addressed: ecology (demography, habitat, distribution) or species management and conservation (conservation status - diagnosis of threats, management actions; Table 3). The findings of studies that addressed demographic aspects were compared with those in the first ecological investigation for this species in Panama (Montgomery and Sunquist 1975; Table 3). 


\section{Results}

Distribution in Colombia. Records from biological collections, seizures and voluntary voluntary deposits of illegal trade (received by CARs and CRRX) reveal localities of occurrence for this species that were previously unknown by the IUCN (Superina et al. 2010). In the case of collection records, such localities of occurrence are found in the departments of Antioquia (municipalities of Urrao and Valdivia), Caldas (Aranzazú), Caqueta (Florencia), Casanare (Yopal), Cauca (El Tambo), Chocó (Bagado), Cundinamarca (Bojacá, Medina, Silvania, Tena), Huila (San Agustín), Meta (Acacias, Cabuyaro, Villavicencio), Quindío (Calarcá, Salento) and Santander (Encino; Appendix 1, Figure 1). In the case of records from illegal trade (CRRX and CARs), these localities of occurrence are found in the departments of Antioquia (municipalities of Amalfi, Amagá, Andes, Angelópolis, Caldas, Ciudad Bolívar, Envigado, Jericó, Yarumal), Caldas (Chinchiná, Manizales, Manzanares, Marquetalia,

Table 1. Records of Choloepus hoffmanni from seizures and voluntary deposits associated with illegal trade received by CARs and CRRX, corresponding to localities of occurrence not included within the distribution reported by IUCN (Superina et al. 2010).

\begin{tabular}{|c|c|c|c|}
\hline & Locality & & \\
\hline Department & Municipality & $\begin{array}{l}\text { Number of } \\
\text { Records }\end{array}$ & Record Source \\
\hline Antioquia & Amalfi & 22 & CRRX/CAR \\
\hline & Amagá & 24 & CRRX/CAR \\
\hline & Andes & 17 & CRRX/CAR \\
\hline & Angelópolis & 19 & CRRX/CAR \\
\hline & Caldas & 25 & CRRX/CAR \\
\hline & Ciudad Bolivar & 27 & CRRX/CAR \\
\hline & Envigado & 14 & CRRX/CAR \\
\hline & Jericó & 21 & CRRX/CAR \\
\hline & Yarumal & 16 & CRRX/CAR \\
\hline Caldas & Chinchiná & 30 & CRRX/CAR \\
\hline & Manizales & 21 & CRRX/CAR \\
\hline & Manzanares & 26 & CRRX/CAR \\
\hline & Marquetalia & 18 & CRRX/CAR \\
\hline & Norcasia & 13 & CRRX/CAR \\
\hline & Palestina & 23 & CRRX/CAR \\
\hline & Samaná & 26 & CRRX/CAR \\
\hline Chocó & El Carmen del Atrato & 4 & CRRX \\
\hline Cundinamarca & Albán & 14 & CRRX/CAR \\
\hline & Facatativá & 21 & CRRX/CAR \\
\hline & Guatavita & 29 & CRRX/CAR \\
\hline & La Mesa & 17 & CRRX/CAR \\
\hline & La Palma & 18 & CRRX/CAR \\
\hline & Mosquera & 25 & CRRX/CAR \\
\hline & San Antonio de Tequendama & 19 & CRRX/CAR \\
\hline & Simijaca & 31 & CRRX/CAR \\
\hline & Soacha & 22 & CRRX/CAR \\
\hline & Topaipí & 16 & CRRX/CAR \\
\hline & Villagómez & 27 & CRRX/CAR \\
\hline & Zipaquirá & 15 & CRRX/CAR \\
\hline Huila & Garzón & 8 & CRRX/CAR \\
\hline & Pitalito & 8 & CRRX/CAR \\
\hline Quindío & Armenia & 20 & CRRX/CAR \\
\hline & Circasia & 24 & CRRX/CAR \\
\hline & Filandia & 28 & CRRX/CAR \\
\hline Risaralda & Pereira & 26 & CRRX/CAR \\
\hline & Dosquebradas & 21 & CRRX/CAR \\
\hline
\end{tabular}


Norcasia, Palestina, Samaná), Chocó (El Carmen del Atrato), Cundinamarca (Albán, Facatativá, Guatavita, La Mesa, La Palma, Mosquera, San Antonio de Tequendama, Simijaca, Soacha, Topaipí, Villagómez, Zipaquirá), Huila (Pitalito and Garzón), Quindío (Armenia, Circasia, Filandia) and Risaralda (Pereira and Dosquebradas; Table 1, Figure 1).

External traits of specimens received in the Xenarthra center for rescue and rehabilitation (CRRX). Based on the observations of the specimens received in CRRX from various parts of the country, three distinctive geographical groups that share some external diagnostic characters were identified (Table 2). C. hoffmanni specimens inhabiting the lowlands (Figure 2a, b, Table 2) show a long body and a dolichocephalic skull. The pelage is yellowish-colored, being shorter and less dense than the one in specimens from the highlands. The head and the body show no obvious differences in pelage color. In juveniles, pelage is short and uniform, with a color that varies from golden to light honey. Young lowland sloths inhabiting the interandean valleys of Cauca and Magdalena rivers show a diamond-shaped light-colored pelage in the ventral surface of the neck. The weight of adult specimens ranges from 5 to $7 \mathrm{~kg}$, whereas newborns weigh 270-300 g.

Choloepus hoffmanni specimens inhabiting the highlands (Figure $2 c$, d, Table 2) show a squareshaped body and a brachycephalic skull. Body pelage is long and dense, dull-colored, ranging from 16-20 cm long in the back and hind limbs. There is a marked difference in pelage color

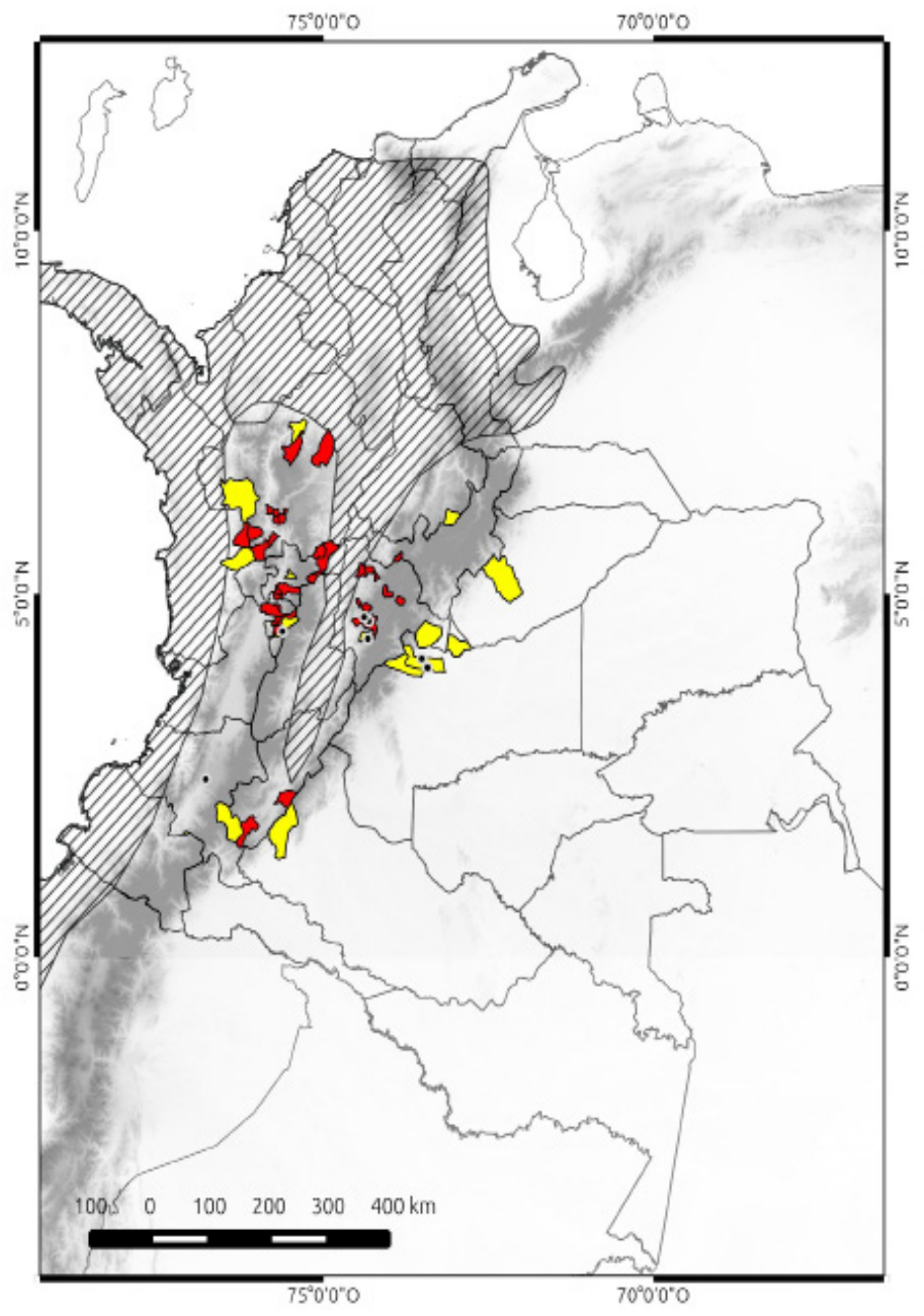

Figure 1. Updated distribution map of Choloepus hoffmanni in Colombia. The area in textured black depicts the distribution reported by IUCN (Superina et al. 2010). Black dots correspond to localities of occurrence not included by IUCN that were obtained from georeferenced records of biological collections; municipalities shaded in yellow correspond to localities of occurrence not georeferenced (see Appendix 1). Municipalities shaded in red correspond to localities of occurrence not reported by IUCN and obtained from records of illegal trade (see Table 1). 
between the head and the body. The pelage of juveniles is dark brown, short and uniform. The weight of adult specimens ranges from 8 to $10 \mathrm{~kg}$, whereas newborns weigh 270-300 g.

Choloepus hoffmanni specimens inhabiting the Colombian central and southern Pacific (Figure $2 \mathrm{e}, \mathrm{f}$, Table 2) show a square-shaped body and a brachycephalic skull. The protruding snout is longer than in specimens from the highlands and lowlands described above. The pelage is dark brown-reddish in the back and light beige ventrally. There is a marked difference in pelage color between head and body, except for specimens inhabiting the central Pacific (Chocó, municipality of Carmen del Atrato), where pelage color in the head and body show no contrasting features.

An additional feature that differentiates sloths from highlands and lowlands is the behavior that characterizes each group. All the highland sloths that were physically examined in the present study displayed aggressive behaviors, being easily annoyed. In some cases, these sloths attacked the observer from tree branches (Figure 2c), displaying a threatening behavior that included circular back-and-forth movements of body and arms, opening and closing of jaws, where they subsequently exhibited a white foam (Figure 2d). As the angry behaviour continued, highlands sloths displayed prominent rosette-shaped glands around the anus. Males used these glands to mark branches, touching them with their anal area. Lowland individuals did not display these aggressive behaviors under stressful situations.
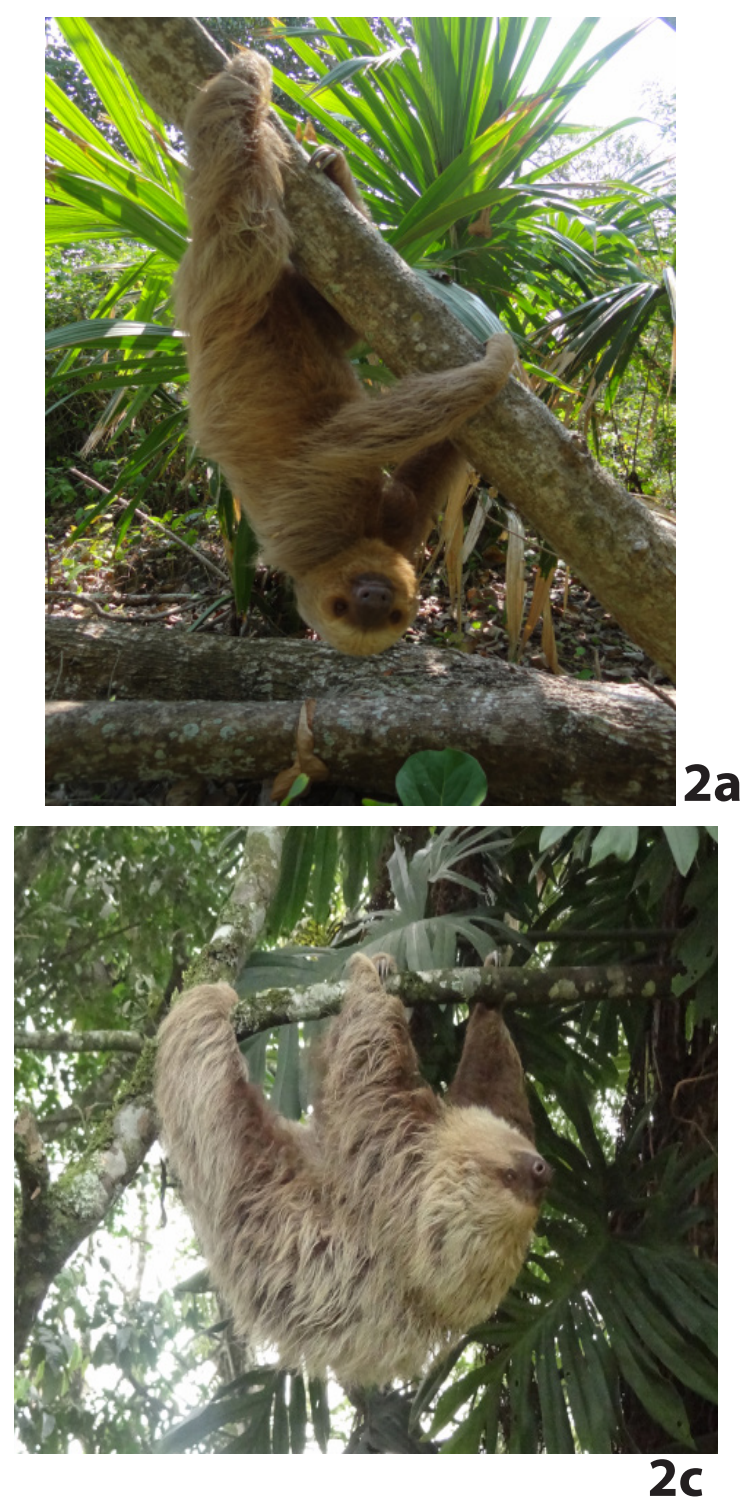
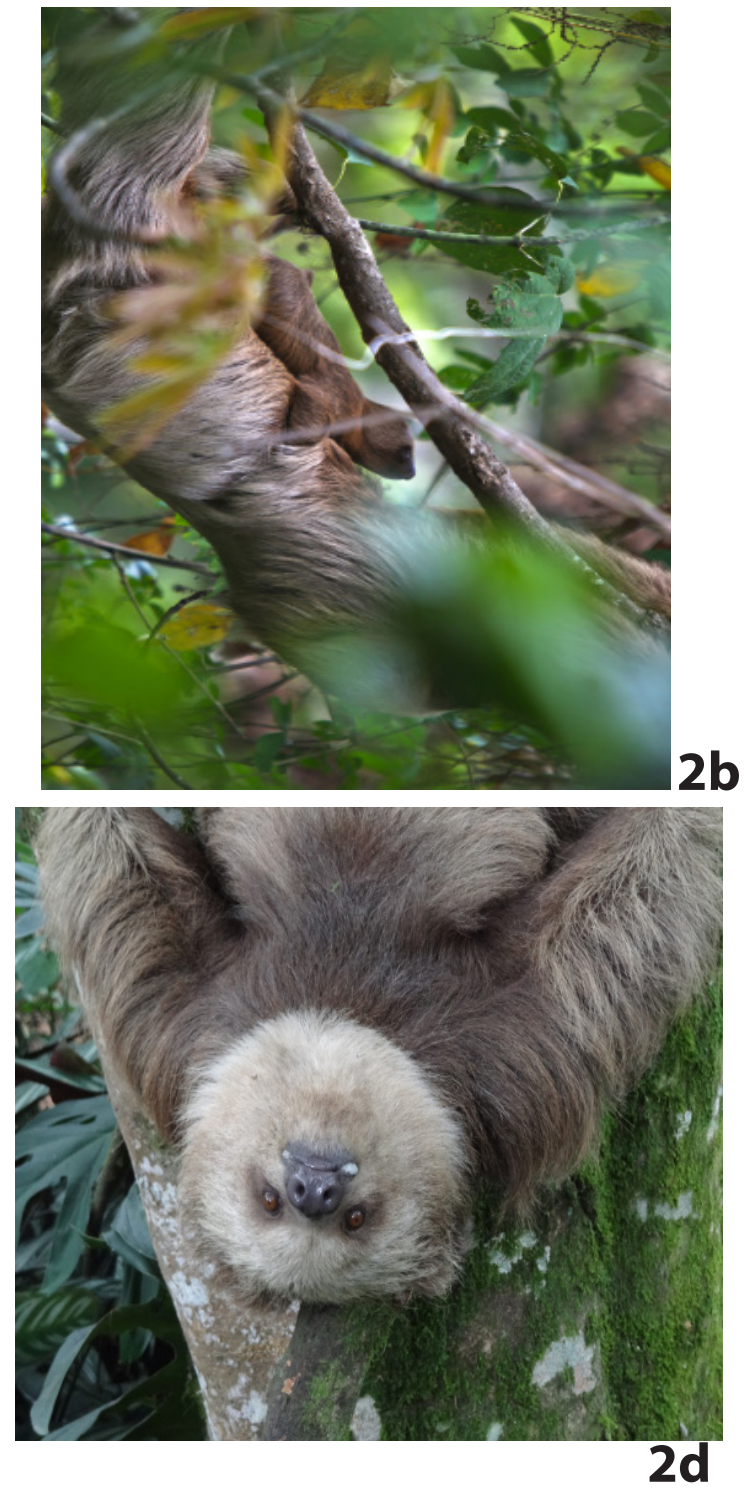

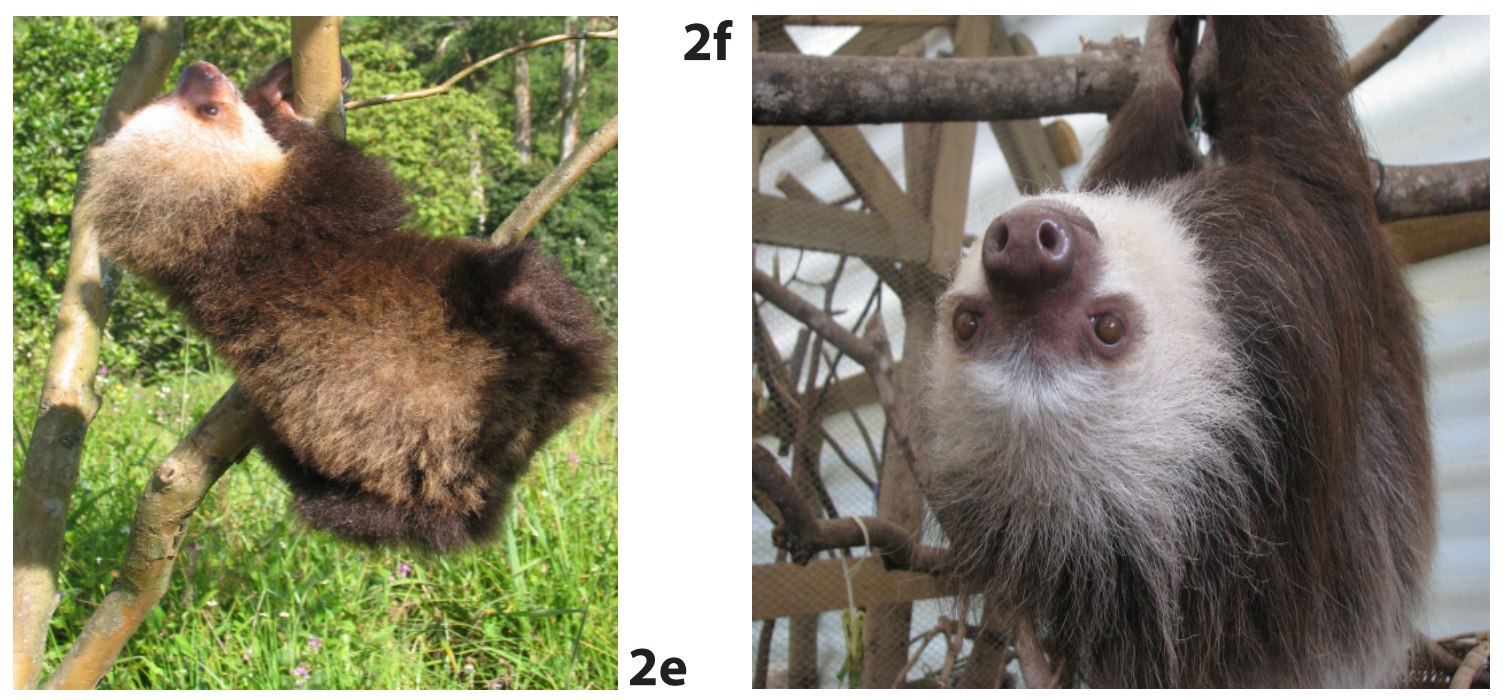

Figure 2. External appearance of Choloepus hoffmanni specimens examined in CRRX. Lowland specimens (a: adult from the Colombian Caribbean region, department of Cordoba; b: juvenile from the Caribbean region, department of Cordoba); highland specimens ( $c$ and d: adults from the Andean region, department of Antioquia); and the Colombian Pacific (e: juvenile from the southern Colombian Pacific region, department of Nariño, municipality of Tumaco; f: adult from the southern Colombian Pacific region, department of Nariño, municipality of Tumaco).

Current state of knowledge in Colombia. In the last two decades, 12 studies have been conducted on this species in Colombia. Six of these studies addressed only management and conservation issues related to this species (conservation status - diagnosis of threats, management actions), two focused only on aspects of its ecology (demography, habitat, distribution), and four investigated both aspects together (Table 3).

In the ecological field, demographic studies of the species (Table 3) reported densities ranging from 0.079 to $1.50 \mathrm{ind} / \mathrm{ha}$ for various regions of the country. A relative abundance of individuals ranging from 0.002-0.0083 ind/ha was reported for Arboletes (Antioquia; Acevedo-Quintero et al. 2011). The only sex ratio reported was 1:2.2 ( $\sigma^{\lambda}:+$ ) for a population in the municipality of Betulia, Santander (Reyes-Amaya et al. 2015). As regards the habitat (Table 3), trees reported as most frequently used were Brunellia sibundoya, Hedyosmum goudotianum and Quercus humboldtii in Bojacá (Cundinamarca; Carmona 2003; Álvarez et al. 2004), Anacardium excelsum, Clarisia biflora, Cupania americana and Guarea gigantea in Quimbaya (Quindío; Aguilar-Isaza and López-Obando 2009) and Brownea ariza in Arboletes (Antioquia; Acevedo-Quintero et al. 2011). Finally, with respect to the distribution (Table 3 ), external morphological differences in fur color were reported between specimens inhabiting the lowlands $(<1,500 \mathrm{~m})$ and the highlands $(\geq 1,500 \mathrm{~m})$ in the department of Antioquia (Moreno 2003).

As regards management and conservation, on the conservation status - diagnosis of threats for the species (Table 3), it was found that the main threats identified for the survival of sloth populations in Colombia were the construction of infrastructure, forest clearance (Carmona 2003; Moreno 2003; Álvarez et al. 2004) and illegal trade (Moreno and Plese 2006; 2014; Humañez-López et al. 2015). As regards management actions for conservation (Table 3), a series of rehabilitation,

Tabla 2. Diagnostic external characters of Choloepus hoffmanni populations from highlands, lowlands and the Colombian Pacific.

\begin{tabular}{|c|c|c|c|c|c|}
\hline & Skull shape & Body shape & Body pelage & $\begin{array}{l}\text { Head/body pelage } \\
\text { contrast }\end{array}$ & Offspring \\
\hline $\begin{array}{l}\text { Lowlands (< } \\
1,500 \mathrm{~m})\end{array}$ & Dolichocephalic & Rectangular & $\begin{array}{l}\text {-yellow dorsally and ventrally - short (up to } 10 \mathrm{~cm} \text {.) } \\
\text { - Lax }\end{array}$ & No & Light honey \\
\hline $\begin{array}{l}\text { Highlands s }(\geq \\
1,500 \mathrm{~m})\end{array}$ & Brachycephalic & Squared & $\begin{array}{l}\text {-dorsally and ventrally - long (up to } 20 \mathrm{~cm} \text {.) } \\
\text { - Dense }\end{array}$ & Yes & Dark brown \\
\hline Colombian Pacific & Brachycephalic & Squared & $\begin{array}{l}\text {-dark brown-reddish dorsally } \\
\text { - light beige ventrally } \\
\text { - Short (up to } 15 \mathrm{~cm} . \text { ) }\end{array}$ & $\begin{array}{l}\text { No (Central Pacific) } \\
\text { Yes (Southern Pacific) }\end{array}$ & - \\
\hline
\end{tabular}




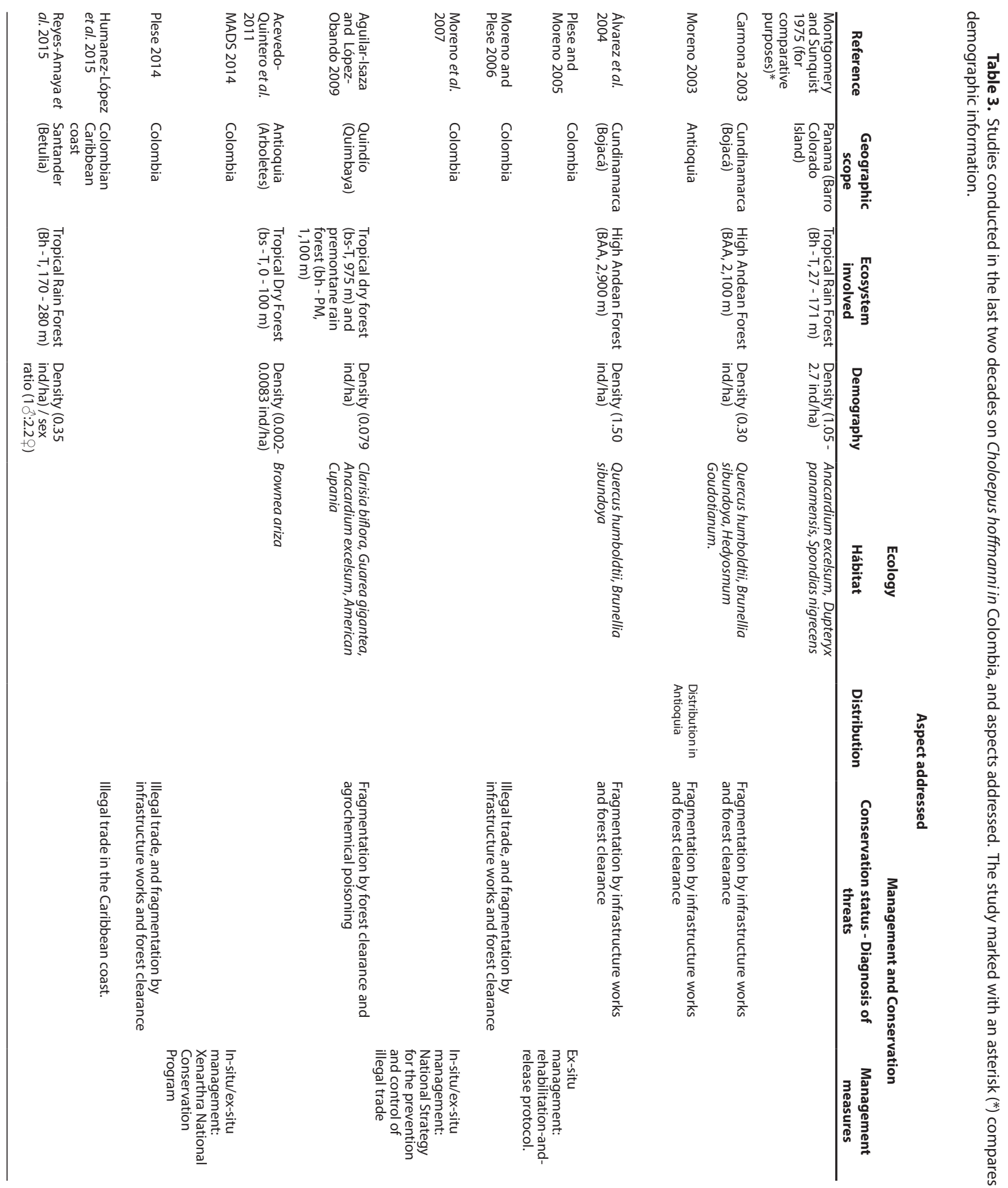

reintroduction and relocation protocols have been issued as accessible tools for those in charge of ex-situ management to achieve a proper rehabilitation and subsequent reintroduction into the natural habitats of this species (Plese and Moreno 2005). The National Strategy for the prevention and control of illegal trade of wild sloth species (Moreno et al. 2007), and the National Program for the Conservation of the Superorder Xenarthra (MADS 2014b) have been issued. These guidelines have set in-situ and ex-situ conservation actions for natural sloth populations facing certain degrees of threat and subject to illegal use and/or exploitation in the country (including C. hoffmanni). 


\section{Discussion}

Distribution in Colombia. The distribution of C. hoffmanni in Colombia established by IUCN locates this species in the north of the country throughout the Caribbean, with two distribution strips that stretch toward the south. The first of these strips stretches along the Colombian Pacific region down to the border with Ecuador in the south; the second strip runs along the Magdalena River interandean valley, up to about half of the Huila department (Superina et al. 2010; Figure 1). This distribution is used by the Ministry of the Environment and Sustainable Development of Colombia (MADS) as the basis for the implementation of conservation and management actions for this species. However, this distribution does not include the type localities recorded previously by Allen (1913) for C. h. agustinus in the departments of Huila (municipality of San Agustín) and Quindío (municipality of Salento) (Appendix 1). Hayssen (2011) proposes a distribution for this species that not only includes the type localities described by Allen (1913), but also encompasses the whole of the Colombian Andes, its interandean valleys and the piedemonte Llanero, but provides no evidence either own or other authors' supporting such distribution range relative to the one established by Superina et al. (2010).

The review of sloth records from biological collections (Appendix 1) and illegal trade records (CARs and CRRX; Table 1) evidence the occurrence of $C$. hoffmanni in 54 municipalities not included in the distribution acknowledged by IUCN (Superina et al. 2010), which belong to 12 departments of the country (Figure 1). These records confirm the occurrence of this species in areas previously covered within the distribution range suggested by Hayssen (2011), to the north and center of the Cordillera Occidental, the Cordillera Central and the Cauca River interandean valley, in addition to the north, center and south of the Cordillera Oriental, the Piedemonte Llanero, and the south of the Magdalena River interandean valley (Figure 1).

The two-toed sloths observed in the department of Chocó (Barbacoas, Baudo and San Juan River valley) had been previously described by Allen (1913) as Choloepus capitalis. Afterwards, Cabrera (1958) denominated these specimens as C. hoffmanni capitalis. The external examination of specimens received in CRRX and collected in the central Pacific and southern Colombia reveals a dark brown-reddish pelage in the dorsal portion of the body, which contrasts with the light-beige color in the ventral portion; the marked contrast of pelage color between head and body coincides with what Allen (1913) described as C. capitalis, and Cabrera (1958) as C. hoffmanni capitalis (Table 2). The above findings support that this subspecies could be distributed along the Colombian Pacific area, contrasting with the distribution suggested by Hayssen (2011), which limits its presence exclusively to the southern Pacific of Colombia and the northern Pacific of Ecuador. However, the specimen from Tumaco (southern Pacific of Colombia) examined in this study, unlike the specimens from the central Pacific examined and the specimens described by Allen (1913), has a white-colored pelage in the head that is considerably more marked than in the other subspecies (Figure $2 \mathrm{f}, \mathrm{g}$ ). In this regards, it is worth stressing that this observation derives from a single specimen, and therefore caution should be exercised when performing specific comparisons.

Choloepus augustinus and C. andinus are taxa nominated by Allen (1913) based on specimens from San Agustin, in the department of Huila, southern Colombia (1,550 m), and from Salento, in the department of Quindío, central Colombia, which were subsequently homologated by Cabrera (1958) as C. h. agustinus. The distribution of this subspecies suggested by Hayssen (2011) makes no altitudinal distinction, reporting it from the Caribbean lowlands in northeast Colombia to the lowlands (interandean valleys) and highlands (cordilleras) of the Andean region in the south of the country. However, the lowland specimens examined show differences in body shape and pelage color relative to highland specimens (Table 2), suggesting that the distribution proposed by Hayssen (2011) for this subspecies should be reviewed.

In Colombia, the species $C$. didactylus has been reported from the north Andean region to the Amazon, including the departments of Antioquia, Santander, Cundinamarca, Quindío, Caldas, 
Cauca, Valle del Cauca, Huila, Meta, Caqueta, and Amazon (Solari et al. 2013). However, Solari et al. (2013) provides no evidence in support of the previous distribution, except for the one already reported by Allen (1913) and Gardner (2008) for the departments of Caqueta and Cundinamarca, respectively. Although the sympatric occurrence of $C$. hoffmanni and $C$. didactylus in the Equatorian and Peruvian Amazon is well known (Gardner 2008), a number of studies in Colombia have reported the departments of Antioquia, Caldas, Cauca, Huila, Quindío, Santander and Valle del Cauca in the Colombian Andes as areas of distribution of $C$. hoffmanni but not of $C$. didactylus (Emmons and Feer 1997; Eisenberg and Redford 1999; Superina et al. 2010). Additionally, the external examination of specimens received in CRRX and collected in the departments of Antioquia, Caldas, Huila and Quindío, did not correspond to C. didactylus.

External traits of specimens received in the Xenarthra center for rescue and rehabilitation (CRRX). The finding of external morphological differences between $C$. hoffmanni specimens from the lowlands (Figure 2a, b) and highlands (Table 2, Figure 2c, d) is consistent with previous reports by Moreno (2003). This author explains that although there are differences in the pelage coloration of some specimens from populations separated by the interandean mountain ranges and valleys, the most pronounced external differences are related to the altitude where specimens were found.

In the case of specimens inhabiting the central Pacific and south of Colombia (Figure 2e, $f$ ), altitude is seemingly unrelated to external characters. The individuals examined that inhabit the Colombian Pacific highlands and lowlands shared traits that, taken together, differ from those observed in sloths from highlands and lowlands in other parts of the country, mainly due to the dark brown-reddish coloration and snout length observed in the Pacific sloths, the latter being larger than in all other specimens examined (Table 2, Figure 2e, $\mathrm{f}$ ).

The external characters addressed in the present work, which differentiate the C. hoffmanni specimens examined into three groups for the lowlands, highlands and the Colombian Pacific (Table 2, Figure 2) , are still insufficient to establish clear taxonomic inferences for this species. However, this finding warrants further analysis. The orogeny of the Andes in Colombia gave rise to the three mountain ranges (eastern, central and western cordilleras) and the interandean valleys, allowing the geographical isolation of wildlife species in the country (Hernández-Camacho et al. 1992). The Cauca River and Magdalena River interandean valleys, along with the Colombian Pacific, have been identified as biogeographically complex zones, where at least three areas of mammal endemism converge (Noguera-Urbano and Escalante 2015.). The ongoing studies on the genetics and distribution of the two-toed sloth in Colombia (Plese, pers. comm.) are expected to shed light on these issues.

Current state of knowledge in Colombia. The differential use of habitats by $C$. hoffmanni seems to be related to the availability and relative abundance of the trees that are preferred for feeding (Montgomery and Sunquist 1978). Likewise, this species prefers trees with a largest diameter at breast height (DBH), a greater height and a wider and lush canopy that facilitates the horizontal and vertical displacement of individuals, providing a number of options for this species to move about and choose from various microhabitats (i. e., descend to the ground to defecate and climb to the canopy for thermoregulation purposes) (Montgomery and Sunquist 1975; 1978). These findings are consistent with those reported in Colombia. This species shows preference toward trees with a DBH greater than $169.64 \mathrm{~cm}$, heights between 15 and $35 \mathrm{~m}$ and canopy cover between 14 and 42 $\mathrm{m}^{2}$ (Aguilar-Isaza and López-Obando 2009). Additionally, it prefers evergreen vegetation, which provides shelter and food during the dry season (Acevedo-Quintero et al. 2011).

The ability of $C$. hoffmanni to adapt to secondary vegetation and agro-ecosystems has been previously suggested (Vaughan et al. 2007; Peery and Pauli 2012). However, human intervention by forest clearance and the construction of infrastructure affects the composition and structure of forests used by this species. These anthropic factors affect the continuity of the canopy and reduce the presence of plant species that provide food and shelter (Carmona 2003; Moreno 
2003; Álvarez et al. 2004; Moreno and Plese 2006; Aguilar-Isaza and López-Obando 2009; Plese 2014). The presence of $C$. hoffmanni in secondary forests with heavy anthropic intervention and agro-ecosystems responds to the anthropic pressure exerted on this species rather to its wide adaptability to these environments (Carmona 2003).

The demographic characteristics of a species are crucial in decision-making for defining its threat status and implement proper management actions for conservation (Morris and Doak 2002). The studies on C. hoffmanni in Barro Colorado (Panama) recorded densities of 1.05 - 2.7 ind./ha in the 1970s (Montgomery and Sunquist 1975). The population studies in humid and dry forests in both lowlands and highlands have yielded markedly different sloth densities for Colombia (Table 3). The lowest population density for Colombia was found in the Andean Cordillera Central, department of Quindío (0.079 ind/ha, Aguilar-Isaza and López-Obando 2009), being the lowest reported so far for this species throughout its distribution range (Table 3 ). The methodological differences of studies on population density for this species have been acknowledged as the primary cause of the broad range of figures reported (Chiarello 2008; Reyes-Amaya et al. 2015). However, the anthropogenic stress exerted on this sloth species in various areas of the country (Cabrera et al. 2011) could be a key factor to interpret the low densities reported (Aguilar-Isaza and López-Obando 2009; Chávez and Arango 2004).

Management and conservation. Habitat fragmentation jeopardizes the survival of $C$. hoffmanni, leading to the isolation, forced migration and decline of the existing populations (Moreno et al. 2007). In the case of the Colombian Caribbean, one of the important distribution areas of C. hoffmanni in the country (Superina et al. 2010), the tropical dry forest has been affected by agriculture and livestock raising, resulting in small forest fragments surrounded by a mosaic of pastureland, stubble and crop patches (Mendoza 1999; Marulanda et al. 2003; García et al. 2014). Recently, the MADS (2014a) has removed C. hoffmanni from the list of endangered species in Colombia, partly due to its alleged ability to adapt to areas with anthropogenic intervention. However, forest deforestation and fragmentation registered throughout the distribution range of this species has been considerable during the second half of the previous decade: between the years 2005-2010, Colombia has recorded an annual loss of 238.273 ha of natural forests, partitioned by natural region as follows: Amazonia $55 \%$, Andes $22 \%$, Caribbean $10 \%$, Orinoquia $7 \%$ and Pacific $4 \%$ (Cabrera et al. 2011). Additionally, there are active areas of intensive deforestation in the San Lucas mountains, Paramillo, Magdalena Medio Santandereano, and Montes de Maria sector, in the boundaries between the departments of Sucre and Bolívar (Cabrera et al. 2011).

Choloepus hofmanni is a species hunted for use as food in some areas of the country, and the offspring and juveniles are trafficked in the black market of pets (Moreno and Plese 2006). Between 2008 and 2012, there was a high incidence of illegal trade for this species in the Colombian Caribbean, with 21.3 \% of total reports (Humañez-López et al. 2015). Between January 2010 and July 2015, the departments of the Andean area evidenced an increase in C. hoffmanni specimens removed from their habitats, as observed in the Antioquean Uraba as well (Plese com. pers.). Added to this is the occasional incidence of forest fires, mostly in the summer, and the expansion of housing buildings in peri-urban countryside areas.

The National Strategy for the prevention and control of illegal trade of wild sloth species (Moreno et al. 2007) and the National Program for the Conservation of the Superorder Xenarthra (MADS 2014b) provide useful tools for the management of $C$. hoffmanni in the country. These documents seek to identify, prioritize and consolidate coordinated actions between the stakeholders responsible for environmental management, aimed to gain a deeper insight and improve the conservation of the Xenarthra species. However, there are currently no specific management tools allowing to perform coordinated actions between the stakeholders and institutions responsible for the management and conservation of this species. In general, the 
actions implemented are isolated initiatives conducted by some entities, a situation similar to the one that occurs with other species subject to conservation in Colombia (Rodríguez-Castro et al. 2015). Conservation actions that involve the protection of the habitat of this species through state plans/strategies for the conservation, restoration and management of the forest coverage in the country indirectly play a role in reducing the pressure on the habitat of the Hoffman's twotoed sloth, and hence contribute to its conservation.

Information gaps. While extensive studies on the natural history of $C$. hoffmanni were conducted in the 1940s (Britton 1941), 1970s (Montgomery and Sunquist 1975; 1978) and 1980s (Montgomery 1985 ) in some countries, there are still a number of aspects of the biology of this species that are still unexplored or have been vaguely described (Chiarello 2008; Peery and Pauli 2012; MADS, 2014b). This fact represents a major challenge for the conduct of an adequate assessment of its conservation status and the development of proper management actions. The review and analysis of the work done on the Hoffmann's two-toed sloth in Colombia over the last two decades reveal that aspects including the distribution, demography (i. e., sex ratio, reproductive seasons), taxonomy and genetics of the populations of this species have been little explored, while aspects such as its conservation status and threats have been widely addressed (Table 3).

\section{Acknowledgments}

We wish to thank the environmental authorities (CARs) in the departments of: Antioquia, Cundinamarca, Caldas, Huila, Quindío and Risaralda, and its officials O. Herrera, A. Ceballos, E. Jimenez, E. Nadachovsky, M. Jaramillo, and N. Zamudio for providing information on the specimens received in the jurisdictions of these agencies. To Y. Castillo (Fundación Wii), L. Castrillón (Wildlife Conservation Society) and A. Delgado (World Land Trust), for their critical inputs to the preliminary drafts of this manuscript. To D. Casagranda (Lillo-CONICET Executing Unit) and J. Lozáno-Florez (Universidad Industrial de Santander) for their guidance during the elaboration of the distribution map. The photographs of the specimens examined were taken by AIUNAU. This manuscript was translated by Maria Elena Sánchez-Salazar with support of THERYA through a CONACYT grant.

\section{Literature Cited}

Acevedo-Quintero, J., D. Sánchez, And T. Plese. 2011. Abundancia y preferencia de hábitat de Bradypus variegatus y Choloepus hoffmanni durante la época seca en dos fragmentos de bosque seco en Arboletes, Antioquia, Colombia. Edentata 12:36-44.

Aguilar-Isaza, N., and D. C. López-Obando. 2009. Estado poblacional actual y hábitat del perezoso de dos dedos (Choloepus hoffmanni, Peters, 1858) en la reserva natural La Montaña del Ocaso, Quimbaya (Quindío), Colombia. Thesis, Universidad del Quindío. Armenia, Colombia.

Alberico, M., A. Cadena, J. Hernández-Camacho, and Y. Muñoz-Saba. 2000. Mamíferos (Synapsida: Theria) de Colombia. Biota Colombiana 1:43-75.

Allen, J. A. 1913. New Mammals from Colombia and Ecuador. Bulletin of the American Museum of Natural History 32:469-484.

Álvarez, S., A. Cadena, and R. Polanco. 2004. Densidad y preferencia de hábitat del perezoso de dos dedos Choloepus hoffmanni en un bosque andino (Bojacá, Cundinamarca, Colombia). Acta Biológica Colombiana 9:118-119.

BritTon, S. W. 1941. Form and Function in the Sloth. The Quarterly Review of Biology 16:13-34.

Cabrera, A. 1958. Catálogo de los mamíferos de América del Sur. Revista del Museo Argentino de Ciencias Naturales Bernardino Rivadavia, Ciencias Zoológicas 4:1-308.

Cabrera, E., D. M. Vargas, G. Galindo, M. C. García, M. F. Ordoñez, K. Vergara, A. M. Pacheco, J. C. Rubiano, 
AND P. GiRALDo. 2011. Memoria técnica de la cuantificación de la deforestación histórica nacional, escalas gruesa y fina. Instituto de Hidrología, Meteorología y Estudios Ambientales (IDEAM). IDEAM, Bogotá, Colombia.

Carmona, M. M. 2003. Densidad y distribución espacial del Perezoso de dos dedos Choloepus hoffmanni Peters 1958, en un bosque Andino, Municipio de Boyacá- Cundinamarca. Thesis. Pontificia Universidad Javeriana. Bogotá, Colombia.

Chávez, M., and N. Arango. 2004. Informe nacional sobre el estado de la biodiversidad en Colombia-2004. Instituto de Investigación de Recursos Biológicos Alexander von Humboldt. Bogotá, Colombia.

Chiarello, A. G. 2008. Sloth ecology: an overview of field studies. Pp. 269-280, in The Biology of the Xenarthra (Vizcaíno, S. F., and W. L. Loughry, eds.). University of Florida Press. Gainesville, U. S. A.

Emmons, L. H., and F. Feer. 1997. Neotropical Rain forest Mammals: A Field Guide. Second edition. The University of Chicago Press. Chicago, U. S. A.

EisenberG, J. F. 1989. Mammals of the Neotropics. Volume 1. The Northern Neotropics: Panamá, Colombia, Venezuela, Guyana, Surinam, French Guyana. The University of Chicago Press. Chicago, U. S. A.

EIsenberG, J. F., AND K. H. Redford. 1999. Mammals of the Neotropics, Volume 3: The Central Neotropics: Ecuador, Peru, Bolivia, Brazil. The University of Chicago Press. Chicago, U. S. A.

García, H., G. Corso, P. Isaacs, and G. Etter. 2014. Distribución y estado actual de los remanentes del Bioma de Bosque seco Tropical en Colombia: insumos para su gestión. Pp. 229-251, in El Bosque seco tropical en Colombia (Pizano, C., and H. García, eds.). Instituto de Investigación de Recursos Biológicos Alexander von Humboldt. Bogotá, Colombia.

Gardner, A. L. 2008. Magnorder Xenarthra. Pp. 127-176, in Mammals of South America, Volume 1. Marsupials, xenarthrans, shrews, and bats (Gardner, A. L., ed.). University of Chicago Press. Chicago, U.S.A.

Hayssen, V. 2011. Choloepus hoffmanni. Mammalian Species 43:37-55.

Hernández-Camacho, J. A., R. O. Hurtado, and T. Walschburger. 1992. Unidades biogeográficas de Colombia. Pp. 105-151, in La Diversidad Biológica de Iberoamérica (Halffter, I. G., ed.). Acta Zoológica Mexicana, Instituto de Ecología, A.C., Ciudad de México, México.

Humanez-López, E., J. Chacon-Pacheco, and T. Plese. 2015. Áreas de extracción de Xenartros en el Caribe colombiano. Edentata 16:65-68.

Kreeger, T. J., J.M. Arnemo, And J. P. RaAth. 2002. Handbook of Wildlife Chemical Immobilization. Wildlife Pharmaceuticals Inc. Fort Collins, U. S. A.

Mads-Ministerio De Ambiente y Desarrollo Sostenible. 2014a. Resolución 0192 de 2014, Diario Oficial No. 49.072. Imprenta Nacional de Colombia, Diario Oficial. Bogotá, Colombia.

Mads-Ministerio De Ambiente y Desarrollo Sostenible. 2014b. Programa Nacional para la Conservación y Uso Sostenible de las especies del Super Orden Xenarthra en Colombia. Ministerio de Ambiente y Desarrollo Sostenible /Fundación AIUNAU. Bogotá, Colombia.

Marulanda, L. O., A. Uribe, P. Velásquez, M. A. Montoya, A. Idarraga, M. C. Lopez, and J. M. Lopez. 2003. Estructura y composición de la vegetación de un fragmento de bosque seco en San Sebastián, Magdalena (Colombia), composición de plantas vasculares. Actualidades Biológicas 25:17-30.

Mendoza, C. H. 1999. Estructura y riqueza florística del bosque seco tropical de la región del Caribe y el Valle del río Magdalena, Colombia. Caldasia 21:70-94.

Montgomery, G. G. 1985. Ecology of living sloths. Pp. 327-343 in: The Evolution and Ecology of Armadillos, Sloths, and Vermilinguas (Montgomery, G. G., ed.). Smithsonian Institution Press. Washington, U.S. A.

Montgomery, G. G., AND M. E. Sunquist. 1975. Impact of sloths on neotropical forest energy flow and nutrient cycling. Pp. 69-98 en Tropical ecology systems: trends in terrestrial and aquatic research (Golley, F. B., and E. Medina, eds.). Springer Verlag. Berlin, Alemania.

Montgomery, G. G., And M. E. Sunquist. 1978. Habitat selection and use by two-toed and three-toed 
sloths. Pp. 329-359, in The ecology of arboreal folivores (Montgomery, G.G., ed.). Smithsonian University Press. Washington, U. S. A.

Moreno, S. 2003. Estado de la distribución, hábitat y estimación del estado de conservación del perezoso de dos uñas (Choloepus hoffmanni) en el área de jurisdicción de Corantioquia. Fundación UNAU, Corantioquia. Medellín, Colombia.

Moreno, S., And T. Plese. 2006. The illegal traffic of sloths and threats to their survival in Colombia. Edentata 7:10-18.

Moreno, S., T. Plese, And C. Rodríguez. 2007. Estrategia nacional para la prevención y control al tráfico ilegal de las especies silvestres de perezosos en Colombia. Ministerio del Medio Ambiente de Colombia. Bogotá, Colombia.

MorRIS, W. F., AND D. F. Doak. 2002. Quantitative conservation biology: the theory and practice of population viability analysis. Sinauer. Sunderland, U. S. A.

Noguera-Urbano, E. A., and T. Escalante. 2015. Áreas de endemismo de los mamíferos (Mammalia) neotropicales. Acta Biológica Colombiana 20:47-65.

Peery, M. Z., ANd J. N. Pauli. 2012. The mating system of a 'lazy' mammal, Hoffmann's two-toed sloth. Animal Behaviour 84:555-562.

Plese, T., And S. Moreno. 2005. Protocolos de rehabilitación, reintroducción y reubicación de perezosos de dos uñas, Choloepus hoffmanni, y de tres uñas, Bradypus variegatus. Fundación UNAU. Corantioquia, Medellín.

Plese, T. 2014. Los perezosos no son osos. Fundación AIUNAU-CVS. Córdoba, Colombia.

Reyes-Amaya, N., D. R. Gutiérrez-Sanabria, Y. Castillo-Navarro, R. A. Rodríguez, andT. Plese. 2015. Información demográfica de Bradypus variegatus, Choloepus hoffmanni y Cyclopes didactylus (Xenarthra: Pilosa) en un bosque húmedo tropical secundario de Santander, Colombia. Mastozoología Neotropical 22:409-415.

Rodríguez-Castro, D., S. Contento, D. Grajales, D. Rodríguez, S. Reyes, N. Reyes-Amaya, and C. Rodríguez. 2015. Evaluación del estado de aplicación del Programa Nacional para la Conservación en Colombia del Oso Andino (Tremarctos ornatus). Biodiversidad Neotropical 5:36-46.

Solari, S., Y. Muñoz-Saba, J. Rodríguez-Mahecha, T. Defler, H. Ramírez-Chaves, and F. Trujillo. 2013. Riqueza, endemismo y conservación de los mamíferos de Colombia. Mastozoología Neotropical 20:301-365.

Superina, M., T. Plese, N. Moraes-Barros, and A. M. Abba. 2010. The 2010 sloth Red List assessment. Edentata 11:115-134.

Vaughan, C., O. Ramirez, G. Herrera, and R. Guries. 2007. Spatial ecology and conservation of two sloth species in a cacao landscape in Limón, Costa Rica. Biodiversity and Conservation 16:2293-2310.

Wetzel, R. M. 1982. Systematics, distribution, ecology, and conservation of South American edentates. Pp. 345-375, in Mammalian Biology in South America (Mares, M. A., and H. H. Genoways, eds.). Special Publication Series of the Pymatuning Laboratory of Ecology, University of Pittsburgh. Pittsburgh, U. S. A.

Submitted: May 30, 2016

Reviewed: July 7, 2016

Accepted: August 24, 2016

Associated editor: Sergio Solari 
Appendix 1. Records of Choloepus hoffmanni from biological collections in localities of occurrence not included by IUCN (Superina et al. 2010). Acronyms of collections where the specimens registered are deposited: American Museum of Natural History (AMNH), Instituto Alexander von Humboldt (IAvH), Alberto Garcia Cadena Mammal Collection - Institute of Natural Sciences (ICN). Coordinates provided according to WGS 84.

\begin{tabular}{|c|c|c|c|c|c|c|c|c|c|}
\hline Map & $\begin{array}{l}\text { Catalog } \\
\text { number }\end{array}$ & $\begin{array}{c}\text { Colectin } \\
\text { date } \\
(y / m / d)\end{array}$ & Departamento & Municipio & Localidad & Latitud & Longitud & $\begin{array}{l}\text { Altitud } \\
\text { (m) }\end{array}$ & Type specimen \\
\hline Yellow & AMNH-136250 & 1939-02-14 & Cundinamarca & Medina & & & & 600 & \\
\hline Yellow & AMNH-33051 & 1911-09-30 & Quindio & Salento & & & & 2,134 & \\
\hline Yellow & AMNH-33909 & 1912-04-19 & Huila & San Agustin & & & & 1,524 & $\begin{array}{l}\text { Choloepus hoffmanni } \\
\text { agustinus (Allen 1913) }\end{array}$ \\
\hline Yellow & AMNH-33911 & $1912-06-23$ & Caquetá & Florencia & & & & 305 & \\
\hline Yellow & AMNH-70534 & $1925-02-01$ & Meta & Villavicencio & & & & & \\
\hline Yellow & AMNH-76776 & 1927-01-01 & Meta & Acacias & & & & & \\
\hline Yellow & AMNH-136301 & 1939-03-15 & Meta & Villavicencio & & & & 500 & \\
\hline Yellow & AMNH-136302 & 1939-03-16 & Meta & Villavicencio & & & & 500 & \\
\hline Yellow & AMNH-139229 & 1940-01-01 & Meta & Villavicencio & & & & 500 & \\
\hline Yellow & AMNH-33039 & 1911-11-08 & Quindio & Salento & El Roble & & & 2,195 & \\
\hline Yellow & AMNH-33052 & 1911-10-31 & Quindio & Salento & & & & 2,164 & $\begin{array}{l}\text { Choloepus hoffmanni } \\
\text { andinus (Allen 1913) }\end{array}$ \\
\hline Yellow & AMNH-33179 & $1912-10-29$ & Chocó & Bagado & & & & 1,000 & \\
\hline Yellow & AMNH-34126 & 1912-11-02 & Chocó & Bagado & & & & & \\
\hline Yellow & AMNH-37790 & $1914-12-21$ & Antioquia & Valdivia & & & & 110 & \\
\hline Yellow & AMNH-69172 & 1922-09-01 & Meta & Villavicencio & & & & & \\
\hline Yellow & AMNH-76775 & 1927-01-01 & Meta & Cabuyaro & $\begin{array}{l}\text { Puerto } \\
\text { Barrigon }\end{array}$ & & & & \\
\hline Yellow & AMNH-37801 & & Antioquia & Valdivia & & & & & \\
\hline Yellow & $\begin{array}{l}\text { IAvH - No } \\
\text { especificado }\end{array}$ & & Casanare & Yopal & & & & & \\
\hline Yellow & $\begin{array}{l}\text { IAvH - No } \\
\text { especificado }\end{array}$ & & Antioquia & Urrao & Rio Calles & & & & \\
\hline Yellow & $\begin{array}{l}\text { IAvH - No } \\
\text { especificado }\end{array}$ & & Caldas & Aranzazu & $\begin{array}{l}\text { Finca las } \\
\text { Garzas }\end{array}$ & & & 2,100 & \\
\hline Yellow & $\begin{array}{l}\text { IAvH - No } \\
\text { especificado }\end{array}$ & & Cundinamarca & Silvania & $\begin{array}{l}\text { Vda El } \\
\text { Triunfo, }\end{array}$ & & & & \\
\hline Black & $\begin{array}{l}\text { IAvH - No } \\
\text { especificado }\end{array}$ & & Cundinamarca & Bojacá & $\begin{array}{l}\text { Fute } \\
\text { Finca San } \\
\text { Cayetano }\end{array}$ & 4.62889 & -74.31361 & 2,590 & \\
\hline Yellow & $\begin{array}{l}\text { IAvH - No } \\
\text { especificado }\end{array}$ & & Quindio & Salento & & & & & \\
\hline Yellow & $\begin{array}{l}\text { IAvH - No } \\
\text { especificado }\end{array}$ & & Cundinamarca & Bojacá & $\begin{array}{l}\text { Vda Fute, } \\
\text { Finca San } \\
\text { Cayetano }\end{array}$ & & & 2,590 & \\
\hline Black & $\begin{array}{l}\text { IAvH - No } \\
\text { especificado }\end{array}$ & & Cauca & El Tambo & & 2.450000 & -76.790000 & & \\
\hline Black & ICN-1764 & 1966-08-05 & Quindio & Calarcá & $\begin{array}{l}\text { Penas } \\
\text { Blancas. }\end{array}$ & 4.486290 & -75.624630 & & \\
\hline Black & ICN-3084 & & Cundinamarca & Tena & $\begin{array}{l}\text { Laguna de } \\
\text { Pedropalo. }\end{array}$ & 4.684813 & -74.388282 & & \\
\hline Black & ICN-3701 & 1950-11-08 & Meta & Villavicencio & Rio Ocoa. & 4.108496 & -73.510504 & & \\
\hline Black & ICN-3702 & 1951-04-07 & Meta & Villavicencio & $\begin{array}{l}\text { Rio } \\
\text { Guayuriba. }\end{array}$ & 3.986625 & -73.426748 & & \\
\hline Black & ICN-4539 & 1974-06-11 & Cundinamarca & Silvania & $\begin{array}{l}\text { La } \\
\text { Aguadita. }\end{array}$ & 4.383788 & -74.329422 & & \\
\hline Yellow & ICN-16394 & & Santander & Encino & $\begin{array}{l}\text { Vereda } \\
\text { Los Micos, } \\
\text { finca La } \\
\text { Esperanza. }\end{array}$ & & & 5,450 & \\
\hline
\end{tabular}


